JAZYKOVEDNÝ ČASOPIS, 2010, roč. 61, č. 2

\title{
SLAVONIC-BALTIC ADDENDA TO THE WORLD LEXICON OF GRAMMATICALIZATION*
}

\author{
BOHUMIL VYKYPĚL
}

VYKYPĚL, Bohumil: Slavonic-Baltic Addenda to the World Lexicon of Grammaticalization. Jazykovedný časopis, 2010, Vol. 61, No.2, pp. 131 - 144. (Bratislava)

In the present paper, the author deals with several processes of grammaticalization in Slavonic and Baltic languages. First he describes the expression of predicative possession and obligation and of future in Northern Slavonic and Baltic languages. Further, he deals with the expression of passive in Baltic languages, with examples of the grammaticalization pathway from 'say' to evidential in Slavonic languages, and with the origin of some complementizer markers in West Slavonic languages. Finally, he briefly discusses two Slavonic and Baltic examples for pathways leading to 'comrade' and 'other'. In addition, he also discusses contactological aspects of the processes in question.

Forty five years ago, Eva Havlová (1965) wrote on the need for a lexicon of semantic changes. In 2002, something like a part of this lexicon appeared when Bernd Heine and Tania Kuteva published their World Lexicon of Grammaticalization (Heine - Kuteva 2002). There is no doubt that this lexicon is rather a work-in-progress and has many problems ${ }^{1}$; on the other hand, it is certainly a usable and useful work which may be amended and complemented in various ways. In the present paper, I would like to contribute to this complementing with a few Slavonic and Baltic examples.

\section{1 'have' and 'obligation'}

Among the grammaticalization pathways leading to predicative possession ( $\mathrm{H}-$ POSSESSIVE), Heine and Kuteva list the well-known path from verbs meaning 'to keep, to hold' to have-verbs and note that "this process is presumably part of the TAKE $>$ HPOSSESSIVE grammaticalization; until it has been established that this is so, we list this as a separate process" (Heine - Kuteva 2002: 186). In the entry TAKE ('to take', 'to seize') > H-POSSESSIVE, they then remark: "this process has been documented abundantly, especially in European languages, where verbs meaning 'take', 'seize', or 'hold' have given rise to HAVE-verbs, that is, to markers of predicative possession" (Heine - Kuteva 2002: 291). However, what is documented in European languages is more likely the former process, that is, the change KEEP > H-POSSESSION; also to be

${ }^{*}$ The present paper was written with the support of a grant from the Czech Science Foundation (Nr. P406/10/1346). I thank Mark Richard Lauersdorf (University of Kentucky, USA) for improving my English.

${ }^{1}$ See Fischer (2003) for some of them. 
subsumed into this grammaticalization pathway are the Germanic examples, English have and German haben: contrary to what Heine and Kuteva write, these verbs do not come from Common Germanic *hafjan 'seize'; in actual fact they continue Common Germanic *habēn, a resultative durative verb derived from the ingressive *hafjan, and meant originally 'keep, hold'. Similarly, some other have-verbs in European languages are to be interpreted in this way, for instance in Czech and Lithuanian (see Vykypěl 2001: 216ff):

\begin{tabular}{|c|c|c|}
\hline ingressive verb 'take' & $\begin{array}{l}\text { durative verb 'keep, hold; have' } \\
\text { derived from the ingressive verb 'take' }\end{array}$ & $\begin{array}{l}\text { 'have' continuing the verb } \\
\text { 'keep, hold; have' }\end{array}$ \\
\hline Old Czech jieti & Old Czech jmieti & Czech mit \\
\hline (Old) Lithuanian tverti & Old Lithuanian turèti & Lithuanian turéti \\
\hline
\end{tabular}

This also means that, at least as far as the European languages in question are regarded, the semantic change 'to keep, to hold' > 'to have' can be said to be "part of the TAKE > H-POSSESSIVE grammaticalization" only in the sense that the verbs undergoing this change are in some cases derivates from verbs meaning 'to take'.

Furthermore, it is well-known and also documented by Heine and Kuteva that have-verbs can develop to expression of obligation (cf. Heine - Kuteva 2002: 243-5); this is also the case in Czech and Lithuanian: Czech mit 'have' + infinitive $=$ 'should, be to'; Lithuanian tureti 'have' + infinitive = 'must'. From an areal point of view, it is interesting to compare Lithuanian and Latvian in this respect (see Holvoet 2007 for a detailed treatment of modality in Baltic).

In Latvian, predicative possession is expressed by the construction of dative + 3rd person of $b \bar{u} t$ 'to be' + nominative:

Man ir grāmata.
I-DAT is book-Nom.SG
'I have a/the book'

Thus, Latvian together with Estonian, Finnish and Russian constitutes the North-Eastern European continuum where predicative possession is expressed by a $b e$-construction in which the expression of possessee is in the nominative or subject form, while Lithuanian together with Polish, Czech, German, etc. belongs to the South-Western European continuum where predicative possession is expressed by a quasi-transitive verb with the accusative or object form of possessee. It is then not surprising that a similar difference exists between Latvian and Lithuanian with respect to expression of obligation:

\begin{tabular}{|c|c|c|c|}
\hline Lithuanian & & & Latvian \\
\hline Jonas & turi & darbuoti. & jāstrāàā. \\
\hline John-Nom & must-3Pers.Pres & work-INF & John-DAT DEB-work-3PERS.PRES \\
\hline
\end{tabular}

Note that in other tenses than the present tense the respective form of $b \bar{u} t$ 'to be' must appear in the Latvian debitive: 
Lithuanian

\section{Jonas}

turèjo

darbuoti.

Latvian

John-Nom

must-3Pers.Past

work-INF

'John had to work'

bija

John-DAT
be-3Pers.Past

jāstrādā.

Deb-work-3Pers.

PRES

Thus, we see a clear parallel between expression of predicative possession and expression of obligation in both languages: in Lithuanian the "possessor" of obligation is in the nominative form, while in Latvian it has the dative form. We can formulate this also in the way that, in the case of Latvian, the grammaticalization pathway H-POSSESSION > OBLIGATION did not apply to an individual word or construction meaning 'have', but to a certain more general mode of construing clauses which was used to express predicative possession.

As to the origin of the Latvian debitive form itself, the debitive prefix $j \bar{a}$ - probably developed from an anaphoric pronoun introducing relative clauses (cf. Holvoet 2007: 185ff). This grammaticalization pathway may possibly be viewed as a fusion of two pathways that are documented by Heine and Kuteva (2002: 97, 108-9), namely DEMONSTRATIVE $>$ COPULA and COPULA $>$ OBLIGATION.

\section{2 future}

B. Heine and T. Kuteva document the well-known fact that expression of both obligation and predicative possession can grammaticalize to expression of future (cf. Heine - Kuteva 2002: 218, 242-3). It is likely that 'obligation' is the connecting semantic component in this grammaticalization pathway, that is, PREDICATIVE POSSESSION $>$ OBLIGATION $>$ FUTURE. In any case, the expression of future with a have-verb meaning both 'predicative possession' and 'obligation' occurs in an incipient stage of grammaticalization in Slavonic languages, e.g. in Old Czech jmieti or in Old Church Slavonic iměti (cf. Křížková 1960: 61ff, 93ff). More interesting are another two Slavonic expressions of future.

2.1 In Ukrainian, there are two forms of the future tense of imperfective verbs, an analytic one and a synthetic one. While the analytic form is the usual Northern Slavonic construction of the future tense of the verb 'to be' and the infinitive, with which we will deal below (2.2), the synthetic form has no parallel in Slavonic languages. It is built with special forms affixed to the infinitive:

$\begin{array}{lll}\text { pysáty 'to write' } & \text { Singular } & \text { Plural } \\ \text { 1st person } & \begin{array}{l}\text { pysáty-mu } \\ \text { pysáty-memo }\end{array} \\ \text { 2nd person } & \begin{array}{l}\text { pysáty-mes } \\ \text { pysáty-me }\end{array} & \begin{array}{l}\text { pysáty-mete } \\ \text { pysáty-mut' }\end{array}\end{array}$

These forms are originally forms of the present tense of the verb játy 'to start, to begin' which meant in Old Ukrainian 'to take' (cf. Humec'ka 1977: 446-7). 
Heine and Kuteva comment on the grammaticalization pathway TAKE ('to take' 'to seize') > FUTURE as follows: "We are listing this case only tentatively here; more research is required on the exact nature and the genetic and areal distribution of it. Conceivably, it is an instance of a more general process whereby process verbs are grammaticalized to auxiliaries denoting tense or aspect functions (...)." (Heine Kuteva 2002: 288).

With respect to areal distribution, one of the three examples listed by Heine and Kuteva is particularly interesting in our case, namely the Hungarian example: in Hungarian the future tense is expressed with the construction of the present tense of the verb fog 'to take' and the infinitive. Naturally, the question arises what relationship there is between the Ukrainian and the Hungarian future tense constructions. According to Krrižková (1960: 130), the center of the Ukrainian construction is in the Eastern dialects of Ukrainian, but it is also used in South-Western dialects bordering Hungarian; both constructions are recorded roughly since the same time (cf. Křížková 1960: 131, Bárczi 2001: 202). Obviously, we would need more information from specialists; nevertheless, a precise argumentation with respect to the direction of possible borrowing will presumably be quite difficult.

With respect, in turn, to the nature of this grammaticalization process, we are obviously dealing with a pathway TO TAKE $>$ TO START, TO BEGIN $>$ FUTURE TENSE. The first step, that is, the change 'to take' > 'to start, to begin', may be documented with Common Slavonic jęti 'to take' that has acquired the meaning 'to start, to begin' in most Slavonic languages, including - as mentioned above - Ukrainian (cf. ESJS 1989: 292); incidentally, according to Kř íž k o vá (1960: 129), the Ukrainian future of the type pysáty-mu seems, in the 19th century, to still have had an ingressive shade of meaning as opposed to purely futural budu + infinitive. Although Heine and Kuteva do not record a grammaticalization pathway leading from verbs meaning 'to start, to begin' to future tense markers (cf. Heine - Kuteva 2002: 51-2), the second step presupposed above, that is, the change 'to start, to begin' $>$ 'future tense', is documented by Old Church Slavonic where the verbs načęti, vъčęti 'to begin, to start' with the infinitive of imperfective verbs can refer to future (cf. Kř́žzová 1960: 74-6, 137ff); another example is the Old Hungarian construction of kezd 'to start, to begin' and the infinitive expressing the future tense (cf. Bárczi 2001: 201-2).

2.2 As is well-known, in Northern Slavonic languages, imperfective verbs form the future tense with a construction containing the future tense of the verb 'to be' and the infinitive; cf. Czech and Russian examples:

Czech

Budu

pracovat.

Russian

Búdu

rabótat'.

be-1Pers.Fut

work-INF

'I will work' 
I am leaving some details aside here, such as the fact that in Polish, the $l$-form of the verb is used as a stylistic variant alongside the infinitive, and that in Sorbian this construction may also apply to perfective verbs. From the point of view of possible grammaticalization pathways, the auxiliary verb occurring in this construction is of interest.

Heine and Kuteva list the Russian form of the Northern Slavonic future construction under the grammaticalization pathway COPULA > FUTURE (Heine - Kuteva 2002: 96); however, this is imprecise, since both in Russian and in other Northern Slavonic languages the auxiliary in question serves as copula only in the future tense. It is more appropriate to categorize this construction under another pathway formulated by Heine and Kuteva, namely CHANGE-OF-STATE ('become') > FUtURE (Heine Kuteva 2002: 64-5). Interestingly enough, Heine and Kuteva refer in this latter lemma of their lexicon to D a 1 (2000), who mentions in passing precisely the Northern Slavonic future form of imperfective verbs as a possible example of the pathway from 'become' to the future tense (cf. Dahl 2000: 359-60); the authors seem thus not to have read his paper to the very end. As regards Dahl himself, he is not entirely sure that the assumption is correct that the auxiliary of the Northern Slavonic construction meant originally 'to become'. In fact, this assumption is wide-spread among etymologists (cf. Berneker 1908-13: 79, Sadnik - Aitzetmüller 1975: 94, Kopečný 1980: 114) and seems to be quite well-founded, since in Old Church Slavonic, Old Czech as well as Old Polish, byti 'to be' meant also 'to become, to come about, to happen' (cf. Gebauer 1903: 126ff, Urbańczyk 1953-55: 182ff, Kurz 1966: 152ff, Koch 1990: 716).

Another issue is the question of how the future meaning of this construction arose. In connection with this, we must first mention the well-known fact that the same construction arose in German:

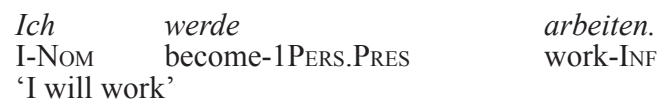

Various ideas on the origin of both the German and the Slavonic construction have been formulated (cf. Kř́žková 1960: 82ff, Ebert 1993: 393 with references), and it is perhaps not necessary to add another one, in particular since the change of ingressive meaning into future meaning seems to be quite natural, as Dahl (2000: 351) also remarks. However, it is remarkable that Heine and Kuteva list precisely only the German example under the lemma CHANGE-OF-STATE ('become') > FUTURE (cf. Heine - Kuteva 2002: 64-5), and thus this grammaticalization pathway seems to be typologically marked. Therefore, it is also natural to ask what is the relation between the German and the Slavonic constructions. As can be expected, the idea that this construction was borrowed has been repeatedly formulated, but there is no consensus regarding the direction of the borrowing. Rö sler (1952) believed that the Slavonic construction had been calqued according to the German construction; 
his assumption was criticized by Křížková (1960: 83ff). Conversely, Le i s s (1985) argued that the German construction had arisen under Slavonic influence, which was questioned by E b e r t (1993: 393). In actual fact, this is perhaps a Scheinproblem. From the "micro-perspective", from which the above-mentioned authors view the issue, it is indeed difficult to prove the borrowing with perfect certainty, that is, to show the exact path of the item in question from one language into the other. However, from the "macro-perspective" of present-day empirical typology, which is presented also by Heine and Kuteva, there exists in this case an obvious correspondence between several languages located in the same area with regard to a linguistic phenomenon, and therefore one can hardly be dealing with mere chance. It is interesting that in this point, we may state another agreement between empirical ("Greenbergian") functionalism and the Prague School (cf. Vykypěl 2009). To wit, the "macro-perspective" mentioned introduces, in fact, the concept of the deep interplay of internal and external factors in the development of language in the spirit of the Prague School. As regards the individual case of the German and Slavonic future constructions, there were surely internal sources and conditions that had given an impulse to formation of the constructions in question, so that the constructions may actually have originated independently of each other, as Křížková (1960: 100) put it; however, the fact that these constructions have been further developed, more firmly established, and more strongly grammaticalized, can be due to a "discovery" of the speakers that, so to speak, their neighbors "do it the same". After all, the finding that the internal and the external (contact-induced) factors of grammaticalization, and of language development in general, are inseparably interconnected is one of the main conclusions of another book by Heine and Kuteva (cf. Heine Kuteva 2005: 265-266).

\section{PASSIVE}

As in the case of the periphrastic future in the Northern Slavonic languages, one may consider various contactological topics also in the case of the passive in the Baltic languages. As is generally known to Balticists, there is a remarkable difference between the form of the construction expressing the passive voice in Lithuanian and that in Latvian. Both languages can express the difference between the dynamic (processual) passive (Vorgangspassiv) and the stative passive (Zustandspassiv), but they have different constructions: whereas in Lithuanian the participle changes according to whether the focus is on the process or on the result, in Latvian this applies to the auxiliary. Cf. the following example:

$\begin{array}{lllllll} & \text { process } & & & \text { state } & \\ \text { Lithuanian } & \text { Knyga } & \text { buvo } & \text { perkama. } & \text { Knyga } & \text { buvo } & \text { pirkta. } \\ & \text { Book-Nom } & \text { Aux('to } & \text { buy-PART. } & \text { Book- } & \text { Aux('to } & \text { buy- } \\ & & \text { be')- } & \text { Pres.PASS } & \text { Nom } & \text { be')- } & \text { PART.Pret.PASS } \\ & & \text { 3PERs.Pret } & & & \text { 3PERS.Pret } & \end{array}$




\begin{tabular}{|c|c|c|c|c|c|c|}
\hline Latvian & $\begin{array}{l}\text { Grāmata } \\
\text { Book-NoM }\end{array}$ & $\begin{array}{l}\text { tika } \\
\text { Aux1('to } \\
\text { become')- } \\
\text { 3PERS.PRET }\end{array}$ & $\begin{array}{l}\text { pirkta. } \\
\text { buy-PART. } \\
\text { PRET.PASS }\end{array}$ & $\begin{array}{l}\text { Grāmata } \\
\text { Book- } \\
\text { Nom }\end{array}$ & $\begin{array}{l}\text { bija } \\
\text { Aux2('to } \\
\text { be')- } \\
\text { 3PERs.PRET }\end{array}$ & $\begin{array}{l}\text { pirkta. } \\
\text { buy- } \\
\text { PART.PRET.PASS }\end{array}$ \\
\hline & $\begin{array}{l}\text { 'The book } \\
\text { (German } D\end{array}$ & $\begin{array}{l}\text { s (being) b } \\
\text { Buch wurd }\end{array}$ & $\begin{array}{l}\text { ght' } \\
\text { gekauft.) }\end{array}$ & $\begin{array}{l}\text { 'The bo } \\
\text { (Germar }\end{array}$ & $\begin{array}{l}\text { Kad been bo } \\
\text { Das Buch wa }\end{array}$ & $\begin{array}{l}\text { 'ght' } \\
\text { gekauft.) }\end{array}$ \\
\hline
\end{tabular}

As is indicated by the German equivalent in parentheses, Latvian can be grouped with German in this respect (although the constructions are functionally not entirely identical with each other; see Wiemer 2004: 304), while Lithuanian matches the Slavonic expression of the passive voice; more generally viewed, Latvian belongs to the "Germanic" areal where the semantic difference in question is expressed by a difference in auxiliaries, whereas Lithuanian is a part of the "Slavonic" areal where this difference is expressed by a difference of the form of the nominal component (cf. e.g. Mathiassen 1997: 136). ${ }^{2}$ These are, in principle, well-known facts described in more detail by specialists in Slavonic and Baltic. In the present paper, we want only to point out some aspects concerning grammaticalization pathways and language contact.

First, it needs to be mentioned that other verbs also function as auxiliaries in the Latvian dynamic passive, although they are far less widespread. Besides Standard Latvian tikt one finds marginally also the verbs tapt and $k l \bar{u} t{ }^{3}{ }^{3}$ What is common to all of the three verbs is that they have approximately the same meaning 'come to, reach; become'. This apparently corresponds to the grammaticalization pathway COME TO > CHANGE-OF-STATE, listed by Heine and Kuteva (2002: 74-5). The second step, that is the change from a verb meaning 'to become' to a passive auxiliary is not registered explicitly by the authors, but it is virtually included in their mention of "a more general process whereby process verbs are grammaticalized to auxiliaries denoting tense or aspect functions" (Heine - Kuteva 2002: 255-256), since the Latvian auxiliaries mentioned as well as their German counterpart werden 'become' in fact denote an aspectual semantic shade in the frame of the category of the passive voice.

In addition, it is interesting to note that the Lithuanian analogue of the Latvian verb tapt, namely Lithuanian tapti 'to become', functioned in the dialects of Kleinlitauen (that is, the former German-ruled part of the territory occupied by the speakers of Lithuanian) as a passive auxiliary, but in contrast to Latvian tapt, the Lithuanian construction with tapti had the resultative meaning (see Kurschat 1876: 295, Otrębski 1956: 235); cf.

${ }^{2}$ We leave aside the peculiar question whether in the stative passive the lexical verb must be obligatorily provided with a prefix expressing the perfective aspect (Lithuanian Knyga buvo nupirkta, Latvian Grämata bija nopirkta). If this were the case, then Latvian would represent a combination of the "Germanic" and the "Slavonic" systems.

${ }^{3}$ The distribution of these verbs would deserve more attention, which unfortunately is not possible in the present paper. The three aforementioned verbs are indicated by most authors, it is, however, noteworthy that neither Rudzīte nor Gāters mention klūt in their surveys of Latvian dialects (cf. Rudzīte 1964:141, 244, 378, Gāters 1977:133). 


\begin{tabular}{|c|c|c|c|c|c|c|}
\hline \multirow{3}{*}{$\begin{array}{l}\text { Lithuanian in } \\
\text { Kleinlitauen }\end{array}$} & \multicolumn{3}{|l|}{ process } & \multicolumn{3}{|l|}{ state } \\
\hline & Knyga & buvo & perkama. & Knyga & tapo & pirkta. \\
\hline & $\begin{array}{l}\text { Book- } \\
\text { Nom }\end{array}$ & $\begin{array}{l}\text { Aux1('to } \\
\text { be')- } \\
\text { 3PERs.PRET }\end{array}$ & $\begin{array}{l}\text { buy-PART. } \\
\text { PrEs.PASS }\end{array}$ & $\begin{array}{l}\text { Book- } \\
\text { Nom }\end{array}$ & $\begin{array}{l}\text { Aux2('to } \\
\text { become')- } \\
\text { 3PERs.PrEt }\end{array}$ & $\begin{array}{l}\text { buy- } \\
\text { PART.Pret.PASS }\end{array}$ \\
\hline \multirow{3}{*}{$\begin{array}{l}\text { Standard } \\
\text { Lithuanian }\end{array}$} & Knyga & buvo & perkama. & Knyga & buvo & pirkta. \\
\hline & $\begin{array}{l}\text { Book- } \\
\text { Nom }\end{array}$ & $\begin{array}{l}\text { Aux('to } \\
\text { be')- } \\
\text { 3PERs.Pret }\end{array}$ & $\begin{array}{l}\text { buy-PART. } \\
\text { PRES.PASS }\end{array}$ & $\begin{array}{l}\text { Book- } \\
\text { Nom }\end{array}$ & $\begin{array}{l}\text { Aux('to } \\
\text { be')- } \\
\text { 3PERs.Pret }\end{array}$ & $\begin{array}{l}\text { buy- } \\
\text { PART.Pret.PASS }\end{array}$ \\
\hline & \multicolumn{3}{|c|}{$\begin{array}{l}\text { 'The book was (being) bought' } \\
\text { (German Das Buch wurde gekauft.) }\end{array}$} & \multicolumn{3}{|c|}{$\begin{array}{l}\text { 'The book had been bought' } \\
\text { (German Das Buch war gekauft.) }\end{array}$} \\
\hline
\end{tabular}

Although this phenomenon would need a closer analysis, we may perhaps say generally that, on the one hand, it bears witness to a more intensive influence of German on the language of Kleinlitauen, and that, on the other hand, it represents one of the cases of imperfect replication in language contact. One may ask whether we have a similar case in Polish: Polish zostać 'to remain, to become' has been used as an auxiliary in the passive construction according to the Low German model with bliven 'to remain, to become', the counterpart of the Standard German werden, but it can combine only with the perfective participle (cf. Wiemer 2004, 298ff, Wiemer - Giger 2005: 70).

Furthermore, it is instructive to compare the situation in Latvian with that in Upper Sorbian, since Upper Sorbian also belongs partially to the aforementioned "Germanic" areal. In Upper Sorbian, there are approximately three different "strata" with respect to the expression of the difference between Vorgangspassiv and Zustandspassiv: In colloquial Upper Sorbian, we find an opposition between the auxiliary wordować 'to become', borrowed from German werden, and the verb być 'to be'; in the language of journalism, there is a native preterital form of the verb 'to be' specialized for expressing the Vorgangspassiv; and in the language of fiction, there is no formal expression in the auxiliary of the difference between dynamic and stative passive (cf. Wiemer - Giger 2005: 101-3, 120). Thus, we see three degrees of the influence of German on Upper Sorbian in this point: no influence in the last case, a stronger influence in the second case manifested by calquing and an even stronger influence in the colloquial language where a foreign verb has itself been borrowed. If we compare this with the situation in Latvian, we see basically two differences, both of which appear to manifest the fact that the influence of German was in the case of the passive construction not as strong as in Upper Sorbian. First, Latvian borrowed only the model, not the auxiliary itself. Second, the periphrastic expression of the passive voice in Latvian is typical of the standard language, whereas the colloquial language uses other strategies for expressing deagentization (cf. e.g. Nau 1998: 38).

Finally, there is one more verb used in Latvian for expressing the dynamic passive, namely nākt 'to come'. This verb occurs in the dialect of Livland (cf. 
Gāters 1977: 133). In their dictionary, Mühlenbach and Endzelin also list the meaning 'to become' for the verb nākt with some evidence from the language of Latvian folklore (cf. Mühlenbach - Endzelin 1925-27: 699). Although this issue would need a more detailed analysis, we may perhaps say preliminary that we are dealing here with the grammaticalization pathway COME TO > CHANGE-OF-STATE, listed by Heine and Kuteva (2002: 74-5), which was then continued to PASSIVE, as was the case with tikt, tapt and klüt.

As a general conclusion, we can say that the relatively high variation of auxiliaries by which a relatively low degree of grammaticalization is manifested, together with the functional-stylistic restriction of the periphrastic passive, gives evidence that we are dealing with a relatively recent contact-induced phenomenon, as it was already pointed out by Otrębski (1956: 236).

\section{SAY $>$ EVIDENTIAL and SAY > QUOTATIVE (and also SAY > SIMILE)}

4.1 One of the numerous grammaticalization pathways leading from verbs meaning 'say' is one which gives rise to evidential markers. We may assume from a purely conceptual point of view that this grammaticalization can go through the stage of quotative, that is, "a marker introducing direct speech"; in other words, we may be dealing with a combination of two grammaticalization pathways listed by Heine and Kuteva, namely SAY > EVIDENTIAL and SAY > QUOTATIVE (cf. Heine - Kuteva 2002: 265, 267-8). This general assumption can be proved by the Czech adverb prý 'allegedly', colloquial Czech prej, Old Czech praj, prej, prý. This adverb developed from the Old Czech verb praviti 'say, talk', although it is not clear exactly which form of the verb served as its basis; most probably it was the third person singular present pravi or the third person singular aorist pravi or possibly the third person plural present pravi < pravie or the first person singular present pravi < prav'u (cf. Gebauer 1894: 138). The development of the expression side of the word in question was a typical one of grammaticalization: reduction of the expressional substance was manifested by the lost of the intervocalic $v$, which can also be interpreted as the irregular change $v^{\prime}>j$, and by the apocope of the final syllable, that is, pravi/pravi $>$ praj $>$ (with the Old Czech regular change $a j>e j$ ) prej; decategorialization of the word was, in turn, manifested by the rise of the hypercorrect form pry that was created from prej at the time of the Old Czech phonological change $y>e j$.

With respect to the semantic side, Old Czech praj, prej, pry had both the evidential meaning and the quotative function (cf. SS 1996: 1070-1, Kopečný 1980: 579); in Modern Czech, the evidential meaning is clearly dominant, but the adverb can also function as a quotative (cf. Hoffmannová 2008).

In addition, there are two Slavonic adverbs corresponding to Czech prý. First, an entirely parallel case is Slovak vraj from vraviet' 'say, talk' that has the same semantics as Modern Czech pry; the situation in Old Slovak is not reconstructable since, in Old Slovak text, the Czech forms praj, prej, prý are used. Second, the East 
Slovenian dialectal adverb pre from praviti 'say' functions as evidential (cf. Pleteršnik 1895: 216).

4.2 Another Common Slavonic verbum dicendi, namely *mъlviti 'speak, say', is the source of the colloquial Russian adverb mol which has the quotative meaning of signaling direct speech; this adverb is recorded already in the 16th century and has developed from molvil 'he spoke, said' or from molvit 'he speaks, says' (cf. Žuravljev - Šanskij 2007: 274 with references). It is interesting that Ukrainian mov, that has the same origin as Russian mol, means 'like, as if', that is, we are dealing in this latter case with the grammaticalization pathway SAY > SIMILE listed by Heine and Kuteva (2002: 268-9); as F r a e n kel (1951: 139) has already remarked, Ukrainian mov can be compared with Lithuanian tar(y)tum, tarsi that has the same meaning ('like, as if'), but a slightly different origin: $\operatorname{tar}(y)$ tum is originally the second person singular subjunctive, tarsi is the second person future, both of the verb tarti 'speak'.

Other Slavonic examples for SAY > EvIDENTIAL, which are, however, less welldocumented and more obscure, are listed in K o pečný (1980: 166, 430, 580; see also Wiemer 2008: 35-7). In contrast, not obscure is the origin of the Lithuanian evidential preposition pasak 'according to', which in fact is the bare stem of the verb pasakyti 'to say (perfective)'.

\section{5 'that'}

Heine and Kuteva document that 'complementizer' (that is, "marker introducing complement clauses") may arise by various grammaticalization pathways, two of them being RELATIVE > COMPLEMENTIZER and DEMONSTRATIVE > COMPLEMENTIZER. In the Slavonic languages, there are the following complementizers marking declara-

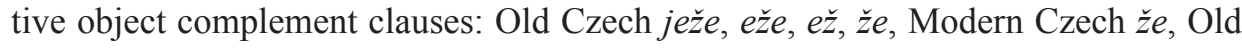
Polish eże, $\dot{z} e$, Polish $\dot{z} e$, Old Upper Sorbian zo, žo, Upper Sorbian zo, Old Church Slavonic ježe (cf. ESJS 1989: 287 with references). Most linguists see in these words the original nominative/accusative singular neuter of the third person pronoun which also functioned as an anaphoric or demonstrative pronoun (Common Slavonic *je; see especially Berneker 1908-13: 416-7, Machek 1968: 723, Bauer 1960: 142). Thus, two grammaticalization pathways recorded by Heine and Kuteva (Heine Kuteva 2002: 106-7, 112-3) are combined in this development: DEMONSTRATIVE > COMPLEMENTIZER and DEMONSTRATIVE $>$ THIRD PERSON PRONOUN.

According to an alternative interpretation, ježe etc. was originally a relative pronoun (Vondrák 1908: 496, Gebauer 1929: 695). This view was criticized by B a u e r (1960: 142); nevertheless, the semantic development presupposed also follows a grammaticalization pathway documented by Heine and Kuteva (2002: 254): RELATIVE > COMPLEMENTIZER. Additionally, 'demonstrative', 'third person' and 'relative' obviously are related concepts, which is also confirmed by the existence of corresponding grammaticalization pathways: DEMONSTRATIVE $>$ THIRD PERSON PRONOUN and DemOnSTRATive > RELATIVE (Heine - Kuteva 2002: 112-5). 
Finally, we point out one contactological topic: it is surely attractive to connect the fact that je(že) 'it, that' developed into a marker of declarative clauses "almost exclusively in West Slavonic", whereas in other Slavonic languages this form acquired other functions (Kopečný 1980: 291-2), with the fact that corresponding German das 'it, that' underwent the same change; however, more detailed research into this question would be needed. In any case, other Slavonic languages, specifically East Slavonic languages, offer another nice example for the grammaticalization pathway W-QUESTION > COMPLEMENTIZER (Heine - Kuteva 2002: 249-250), since the pronoun 'what' functions here also as a marker of declarative sentences: cf. Ukrainian:

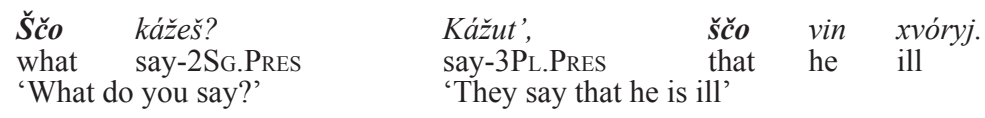

\section{ONE $>$ OTHER}

Heine and Kuteva register various grammaticalization pathways leading from numerals meaning 'one'; one of them which does not seem to be very wide-spread according to the data offered by the authors is ONE > OTHER (cf. Heine - Kuteva 2002: 223). Nevertheless, we can add another example: Common Slavonic *inъ 'other'. Although the details are not entirely clear, most etymologists presuppose that this word developed from the Indo-European numeral *oinos 'one'; the original meaning 'one' was maintained in some Slavonic compounds such as Old Church Slavonic inorogz 'unicorn' and derivates such as Old Church Slavonic inokb 'monk' (cf. Kopečný 1980: 313ff, ESJS 1989: 244-5 with references). Heine and Kuteva comment on this grammaticalization pathway as follows: "More research is required on the contextual conditions leading to this grammaticalization." (Heine - Kuteva 2002: 223).

As regards the Slavonic example, an interpretation of these conditions has traditionally been offered: etymologists assume that the meaning 'other' arose in contrastive contexts when inb 'one' was used in two clauses referring to two possibilities to be chosen, and the second in r referred thus to the second possibility, that is, to another possibility (cf. Machek 1968: 227, Kopečný 1980: 318, ESJS 1989: 245).

\section{COMRADE}

Semantically more amusing is the grammaticalization of nouns meaning 'comrade' (with this notion standing in Heine and Kuteva "for a number of role relations, including 'companion', 'friend', 'neighbor', 'relative"'). Heine and Kuteva list two grammaticalization pathways leading from this meaning (cf. Heine - Kuteva 2002: 91-3).

The first one is COMRADE > COMITATIVE. The authors remark that "the data supporting this pathway are not entirely satisfactory" (Heine - Kuteva 2002: 92), the 
reason for this evaluation being perhaps the fact that the examples they adduce are based on reconstruction. However, we can add one Baltic example which is more certain in this respect: Lithuanian drauge 'together' is originally the locative singular form of the noun draugas 'friend, comrade'. We can observe two things here. First, the grammaticalization has reached only the adverbial stage, and has not progressed to the stage of a comitative affix. Second, we can apparently posit an areal relation, if the etymology of the Estonian and Sami comitative case markers listed by Heine and Kuteva is right and these markers really come from a noun meaning 'comrade'; however, it is striking, on the other hand, that no such adverb exists in Latvian.

The second pathway listed by Heine and Kuteva is COMRADE > RECIPROCAL; they adduce also the Russian construction drug druga 'each other':

$\begin{array}{ll}\text { drug } & \text { druga } \\ \text { friend-Nom.SG } & \text { friend-Acc.SG } \\ \text { 'each other' } & \end{array}$

However, they do not mention that another grammaticalization pathway can possibly be posited on the basis of the Slavonic languages, namely COMRADE $>$ SECOND, OTHER: as is generally known, the Common Slavonic substantive *drugb 'friend' is continued in Slavonic languages, on the one hand, by substantives with the same meaning, and, on the other hand, by adjective numerals and pronouns meaning 'second' and/or 'other' (cf. ESJS 1989: 151 with references).

\section{References ${ }^{* *}$}

BÁRCZI, Géza 2001. Geschichte der ungarischen Sprache. Innsbruck: Institut für Sprachen und Literaturen. (Innsbrucker Beiträge zur Kulturwissenschaft, Sonderheft 110.)

BAUER, Jaroslav 1960. Vývoj českého souvětí [Development of the Czech Compound Sentence]. Praha: Nakladatelství ČSAV. (Studie a práce lingvistické, 4.)

BERNEKER, Erich 1908-13. Slavisches etymologisches Wörterbuch. I. Heidelberg: Winter. (Indogermanische Bibliothek, I/2/2. = Sammlung slavischer Lehr- und Handbücher, I/1.)

DAHL, Östen 2000. Verbs of becoming as future copulas. In: Tense and Aspect in the Languages of Europe. Ed. by Östen Dahl. Berlin - New York: Mouton de Gruyter, 351-61. (Eurotyp, 6.)

EBERT, Peter 1993. Syntax. In: Frühneuhochhochdeutsche Grammatik. Ed. by Oskar Reichmann and Klaus-Peter Wegera. Tübingen: Niemeyer, 313-484. (Sammlung kurzer Grammatiken deutscher Dialekte, A/12.)

ESJS 1989 = Etymologický slovník jazyka staroslověnského [Etymological Dictionary of the Old Church Slavonic Language]. Ed. by Eva Havlová et al. Praha: Academia 1989ff.

FISCHER, Olga 2003. Review of Heine and Kuteva 2002. Functions of Language 10, 136-143.

FRAENKEL, Ernst 1951. Miszellen zur balto-slavischen Syntax. Zeitschrift für vergleichende Sprachforschung 69, 139-149.

GĀTERS, Alfrēds 1977. Die lettische Sprache und ihre Dialekte. The Hague etc.: Mouton. (Trends in Linguistics, State-of-the-Art Reports, 9.)

** V príspevku neuvádzame bibliografické jednotky a odkazy podl’a úzu Jazykovedného časopisu. Rešpektujeme medzinárodnú normu, ktorú uplatnil autor štúdie. (pozn. red.) 
GEBAUER, Jan 1894. Historická mluvnice jazyka českého [Historical Grammar of the Czech Language]. I. Praha - Vídeň: Tempský.

GEBAUER, Jan 1903. Slovník staročeský [Old Czech Dictionary]. I. Praha: Unie.

GEBAUER, Jan 1929. Historická mluvnice jazyka českého [Historical Grammar of the Czech Language]. IV. Ed. by František Trávníček. Praha: Česká akademie věd a umění.

HAVLOVÁ, Eva 1965. O potřebě slovníku sémantických změn [On the need for a lexicon of semantic changes]. Jazykovédné aktuality 1965, Nr. 4, pp. 3-4

HEINE, Bernd - KUTEVA, Tania 2002. World Lexicon of Grammaticalization. Cambridge: Cambridge University Press.

HEINE, Bernd - KUTEVA, Tania 2005. Language Contact and Grammatical Change. Cambridge: Cambridge University Press.

HOFFMANNOVÁ, Jana 2008. Role českého prý / prej / pré při vyjadřování reproduktivních a modálních významů [The role of the Czech words prý / prej / pré in expressing evidential (reportative) and epistemic meanings]. In: Wiemer - Plungjan 2008: 149-64.

HOLVOET, Axel 2007. Mood and Modality in Baltic. Kraków: Wydawnictwo Uniwersytetu Jagiellońskiego. (Baltica Varsoviensia, 6.)

HUMEC'KA, L. L. (ed.) 1977. Slovnyk staroukrajins'skoji movy XIV-XV st. [Dictionary of the Old Ukrainian Language of the 14th and 15th c.]. I. Kyjiv: Naukova dumka.

KOCH, Christoph 1990. Das morphologische System des altkirchenslavischen Verbums. München: Fink. (Münchner Universitäts-Schriften, 22.)

KOPEČNÝ, František (ed.) 1980. Etymologický slovník slovanských jazyků. Slova gramatická a zájmena [Etymological Dictionary of the Slavonic Languages: Grammatical words and pronouns]. II. Praha: Academia.

KŘİŽKOVÁ, Helena 1960. Vývoj opisného futura vjazycích slovanských, zvláště v ruštině [Development of the Periphrastic Future in the Slavonic Languages, especially in Russian]. Praha: SPN. (Acta Universitatis Palackianae Olomucensis, Facultas philosophica 4, Philologica II.)

KURSCHAT, Friedrich 1876. Grammatik der littauischen Sprache. Halle: Verlag der Buchhandlung des Waisenhauses.

KURZ, Josef (ed.) 1966. Slovnik jazyka staroslověnského [Dictionary of the Old Church Slavonic Language]. I. Praha: Academia.

LEISS, Elisabeth 1985. Zur Entstehung des neuhochdeutschen analytischen Futurs. Sprachwissenschaft 10, 250-273.

MACHEK, Václav 1968. Etymologický slovník jazyka českého [Etymological Dictionary of the Czech Language]. Praha: Academia.

MATHIASSEN, Terje 1997. A Short Grammar of Latvian. Columbus (OH): Slavica Publishers.

MÜHLENBACH, K. - ENDZELIN, J. 1925-27. Lettisch-deutsches Wörterbuch. II. Riga: Lettischer Kulturfonds.

NAU, Nicole 1998. Latvian. München - Newcastle: Lincom Europa. (Languages of the World / Materials, 217.)

OTRĘBSKI, Jan 1956. Gramatyka języka litewskiego [Grammar of the Lithuanian Language]. III. Warszawa: Państwowe Wydawnictwo Naukowe.

PLETERŠNIK, M. 1895. Slovensko-nemški slovar [Slovenian-German Dictionary]. II. Ljubljana: Knezoškofijstvo.

RÖSLER, Karl 1952. Beobachtungen und Gedanken über das analytische Futurum im Slavischen. Wiener Slavistisches Jahrbuch 2, 103-149.

RUDZĪTE, Marta 1964. Latviešu dialektologija [Latvian Dialectology]. Rīga: Latvijas valsts izdevniecība.

SADNIK, Linda - AITZETMÜLLER, Rudolf 1975. Vergleichendes Wörterbuch der slavischen Sprachen. I. Wiesbaden: Harrassowitz.

Jazykovedný časopis, 2010, roč. 61, č. 2 
SS 1996 = Staročeský slovnik. paběničský - pravý [Old Czech Dictionary: paběničský - pravý]. Praha: Academia 1996.

URBAŃCZYK, Stanisław (ed.) 1953-55. Stownik staropolski [Old Polish Dictionary]. I. Warszawa: PAN.

VONDRÁK, Wenzel 1908. Vergleichende Slavische Grammatik. II. Göttingen: Vandenhoeck und Ruprecht.

VYKYPĚL, Bohumil 2001. Zwei lettonistische Bemerkungen. In: GRAMMATICVS. Studia linguistica Adolfo Erharto quinque et septuagenario oblata. Ed. by Ondřej Šefč́́k and Bohumil Vykypěl. Brno: Masarykova univerzita, 211-223.

VYKYPĚL, Bohumil 2009. Empirical Functionalism and the Prague School. München: Lincom Europa. (Travaux linguistiques de Brno, 6.)

WIEMER, Björn 2004. The evolution of passives as grammatical constructions in Northern Slavic and Baltic languages. In: What Makes Grammaticalization? A look from its fringes and its components. Ed. by Walter Bisang, Nikolaus P. Himmelmann and Björn Wiemer. Berlin - New York: Mouton de Gruyter, 271-321. (Trends in Linguistics, Studies and Monographs, 158.)

WIEMER, Björn 2008. Lexikalische Markierungen evidenzieller Funktionen: zur Theoriebildung und empirischen Forschung im Slavischen. In: Wiemer-Plungjan 2008: 5-49.

WIEMER, Björn - GIGER, Markus 2005. Resultativa in den nordslavischen und baltischen Sprachen. Bestandaufnahme unter arealen und grammatikalisierungstheoretischen Gesichtspunkten. München: Lincom Europa. (LINCOM Studies in Language Typology, 10.)

WIEMER, Björn - PLUNGJAN, Vladimir A. (eds.) 2008. Lexikalische Evidenzialitäts-Marker in slavischen Sprachen. München - Wien: Gesellschaft zur Förderung slawistischer Studien. (Wiener Slawistischer Almanach, Sonderband 72.)

ŽURAVLEV, A. F. - ŠANSKIJ, N. M. (eds.) 2007. Ėtimologičeskij slovar' russkogo jazyka [Etymological Dictionary of the Russian Language]. X. Moskva: Izdatel'stvo Moskovskogo universiteta.

\section{Resumé}

\section{SLOVANSKO-BALTSKÁ ADDENDA K WORLD LEXICON OF GRAMMATICALIZATION}

Před více než 45 lety psala Eva Havlová o potřebě slovníku sémantických změn. Něco jako část takového slovníku vyšlo v roce 2002 v podobě Světového lexikonu gramatikalizace od Bernda Heineho a Taniy Kutevové. Ačkoli jejich Lexikon má nemálo otazníků, jistě ho lze využít jako základu pro další práci a různě jej doplňovat. $V$ tomto príspěvku přinášíme některá doplnění z oblasti slovanských a baltských jazyků.

Dobře dokumentovaný př́ípad pro gramatikalizační kanál DRŽET > MíT představuje např. české mít a litevské turèti téhož významu; obě tato slovesa pak ilustrují také další gramatikalizační vývoj v linii MíT > POVINNOST. Pro dva gramatikalizační kanály vedoucí k futuru uvádíme dva př́klady ze slovanských jazyků: vzí > FUTURuM v ukrajinském futuru typu pysáty-mu (zde navíc uvažujeme o možnosti vlivu mad'arštiny) a ZMĚNA STAVU > FUTURUM v severoslovanském futuru typu českého budu pracovat (zde navíc řešíme otázku vlivu němčiny na vznik této konstrukce). Dále v areálových souvislostech pojednáváme o lotyšských pasivních konstrukcích typu tikt/tapt/kļūt + infinitiv jako príkladech gramatikalizačního kanálu DOSTAT SE $>$ ZMĚNA STAVU $>$ PASIVUM. Jako o př́kladu gramatikalizačních kanálů ŘíCT > EVIDENCIÁL a Říct > QUOTATIV pak pojednáváme o českém prý a stručněji i o jiných slovanských partikulích. Jako další príklad gramatikalizace vedoucí od relativa/demonstrativa ke spojce uvádějící vedlejší obsahovou větu uvádíme severoslovanské spojky typu českého že (a stručně přitom poukazujeme na možnost vlivu němčiny). Konečně pro gramatikalizační kanál vedoucí od číslovky 1 k zájmenu či adjektivu 'jiný' krátce zmiňujeme další př́klad v praslovanském *inz a jako př́klad částečné gramatikalizace substantiva 'př́ítel' v komitativ uvádíme litevské drauge ‘společně'. 